\title{
GAMBARAN KARAKTERISTIK PASIEN HIV/AIDS YANG MENDAPAT ANTIRETROVIRAL THERAPY (ART)
}

\author{
Andi Juhaefah ${ }^{1}$, Swandari Paramita ${ }^{2}$, Khemasili Kosala $^{3}$, Carta A. Gunawan ${ }^{4}$, \\ Yuniati $^{5}$ \\ ${ }^{1}$ Program Studi Kedokteran, Fakultas Kedokteran, Universitas Mulawarman \\ ${ }^{2}$ Laboratorium IImu Kedokteran Komunitas, Fakultas Kedokteran, Universitas \\ Mulawarman \\ ${ }^{3}$ Laboratorium Farmakologi, Fakultas Kedokteran, Universitas Mulawarman \\ ${ }^{4}$ Laboratorium IImu Penyakit Dalam, Fakultas Kedokteran, Universitas Mulawarman \\ ${ }^{5}$ Laboratorium Mikrobiologi, Fakultas Kedokteran, Universitas Mulawarman \\ Email: efaandy20@gmail.com, swandariparamita@gmail.com, khemasili_k@yahoo.com
}

\begin{abstract}
ABSTRAK
Human Immunodeficiency Virus (HIV) adalah virus yang menyebabkan Acquired Immuno Deficiency Syndrome (AIDS). Kondisi AIDS adalah suatu kumpulan gejala berkurangnya kemampuan pertahanan diri yang disebabkan oleh masuknya HIV dalam tubuh seseorang. Penelitian ini bertujuan untuk mengetahui gambaran karakteristik pasien HIV/AIDS yang mendapat Antiretroviral Therapy (ART) di 9 Puskesmas di Kota Samarinda. Metode yang digunakan adalah penelitian deskriptif dengan penelusuran data bersifat retrospektif. Penelitian ini dilakukan di 9 fasilitas layanan kesehatan yang merupakan satelit ART di Kota Samarinda yaitu Puskesmas Temindung, Sempaja, Bengkuring, Sidomulyo, Palaran, Bantuas, Trauma Center, Sungai Siring dan Karang Asam. Sampel adalah 333 pasien HIV/AIDS yang mendapatkan ART dalam kurun waktu Januari 2016-Desember 2018, data diambil dari data pasien berbasis komputer. Hasil penelitian menujukkan pasien HIV/AIDS paling banyak berusia antara 20-29 tahun $(47,7 \%)$, didominasi oleh laki-laki $(70,9 \%)$, berpendidikan SMA $(52,3 \%)$, pasien dengan status belum menikah $(47,1 \%)$ dan bertempat tinggal di Kota Samarinda $(88,0 \%)$. Penyakit ini sebagian besar diperoleh dari laki-laki yang berhubungan seks dengan lakilaki (LSL) sebagai faktor risiko yang paling dominan (39,0\%). Pasien sebagian besar melakukan pengobatan di Puskesmas Temindung, dimana obat antiretroviral yang digunakan merupakan terapi lini I dengan rejimen Tenofovir + Emtricitabine + Evafirenz $(85,3 \%)$. Diharapkan penelitian ini dapat bermanfaat untuk program pencegahan dan tatalaksana HIV/AIDS di masa yang akan datang.
\end{abstract}

Kata Kunci: Karakteristik Pasien, HIV/AIDS, ART

\section{PENDAHULUAN}

(HIV) adalah virus yang menyebabkan Acquired Immune Deficiency Syndrome (AIDS). Kondisi AIDS adalah suatu kumpulan gejala berkurangnya kemampuan pertahanan diri yang disebabkan oleh masuknya HIV dalam tubuh seseorang. Orang dengan HIV dan AIDS (ODHA) adalah orang yang telah terinfeksi HIV (Kementerian Kesehatan RI, 2015).

HIV dapat ditularkan melalui hubungan seksual tanpa kondom (vaginal atau anal), dan seks oral dengan orang yang terinfeksi; transfusi darah yang terkontaminasi; dan berbagi jarum suntik yang terkontaminasi, alat suntik, peralatan bedah, atau instrumen tajam lainnya. Hal ini juga dapat ditularkan antara ibu dan bayinya selama kehamilan,

\footnotetext{
*Corresponding Author :

Andi Juhaefah

Program Studi Kedokteran, Fakultas Kedokteran

Universitas Mulawarman

Email : efaandy20@gmail.com
} 
persalinan, dan menyusui (World Health Organization [WHO], 2017ª). Populasi kunci dalam penularan HIV/AIDS meliputi pengguna napza suntik (penasun); Wanita Pekerja Seks (WPS) langsung maupun tidak langsung; pelanggan/pasangan seks WPS; serta gay, waria, dan Laki pelanggan/pasangan Seks dengan sesama Laki (LSL) (Kementerian Kesehatan RI, 2015).

Menurut perkiraan $\mathrm{WHO}$ dan Joint United Nations Programme on HIV and AIDS (UNAIDS), 36,7 juta orang, hidup dengan HIV di seluruh dunia pada akhir tahun 2016 (WHO, 2017b). HIV/AIDS di Indonesia merupakan salah satu epidemi pertumbuhan tercepat di Asia. Pada tahun 2007, tingkat prevalensi HIV/AIDS di Indonesia berada pada peringkat ke-99 di dunia, namun karena rendahnya pemahaman akan gejala penyakit dan stigma sosial yang tinggi yang menyertainya, hanya $5-10 \%$ penderita HIV/AIDS yang benar-benar didiagnosis dan dirawat (UNAIDS, 2018).

Jumlah kasus HIV di Kalimantan Timur tahun 2017 sebanyak 1.202 orang, dengan jumlah total kumulatif kasus HIV hingga tahun 2017 sebanyak 5.257 orang. Kalimantan Timur termasuk peringkat 8 tertinggi di Indonesia dengan 439 laporan kasus HIV pada triwulan keempat tahun 2017. Sementara itu, jumlah kasus AIDS di Kalimantan Timur tahun 2017 sebanyak 358 orang, dengan jumlah total kumulatif kasus AIDS hingga tahun 2017 sebanyak 1.401 orang. Kalimantan Timur termasuk peringkat 5 tertinggi di Indonesia dengan 230 laporan kasus AIDS pada triwulan keempat tahun 2017. Saat ini, di Kalimantan Timur terdapat 1.116 kasus hidup AIDS dan 285 kasus meninggal AIDS, dengan case rate 30,9 per 100.000 penduduk (Kementerian Kesehatan RI, 2018).
Menurut penelitian yang dilakukan di RSUP. Dr. M. Djamil Padang tahun 2015, dilaporkan bahwa dari 89 pasien HIV/AIDS, didapatkan bahwa 76,4\% merupakan pasien laki-laki, dengan persentase tertinggi pada kelompok usia 26-35 tahun $(41,57) \%$. Didominasi oleh pasien yang menikah $(58,43 \%)$ dan berpendidikan SMA $(56,18 \%)$, serta sebagian besar penyakit ini diperoleh melalui hubungan seksual $(61,8)$ (Yuliandra, Nosa, Raveinal, \& Almasdy, 2017). Penelitian yang dilakukan di RSUD. Dr. Pirngadi Medan tahun 2015, dilaporkan bahwa dari 105 kasus pasien HIV/AIDS yang berobat jalan, didapatkan proporsi pasien HIV/AIDS paling banyak pada kelompok usia 30-39 tahun (46,8\%), laki-laki (34,8\%), SMA (67,8\%), menikah $(46,7 \%)$, dan heteroseksual (64,3\%) (Purba, 2016).

\section{METODE PENELITIAN}

Penelitian ini menggunakan metode penelitian deskriptif retrospektif untuk mengetahui gambaran karakteristik pasien HIV/AIDS di 9 Puskesmas di Kota Samarinda periode 2016-2018. Sampel yang digunakan dalam penelitian ini adalah seluruh pasien HIV/AIDS yang datang berobat di Puskesmas Temindung, Sempaja, Bengkuring, Sidomulyo, Palaran, Bantuas, Trauma Center, Sungai Siring, dan Karang Asam periode Januari 2016-Desember 2018. Pengambilan sampel dilakukan dengan total sampling. Variabel pada penelitian ini adalah usia, jenis kelamin, domisili, status pendidikan, status marital, faktor risiko, asal puskesmas, dan jenis ARV. Data penelitian yang diambil adalah data sekunder yang diambil dari data pasien HIVIAIDS berbasis komputer. Analisa data dengan analisis

\section{*Corresponding Author:}

\section{Andi Juhaefah}

Program Studi Kedokteran, Fakultas Kedokteran

Universitas Mulawarman

Email : efaandy20@gmail.com 
univariat, yang ditampilkan dalam bentuk diagram, tabel, dan narasi.

\section{HASIL DAN PEMBAHASAN}

Hasil penelitian menemukan bahwa selama periode 2016-2018, didapatkan sampel sebanyak 333 pasien. Dari 333 pasien HIV/AIDS tersebut, 78 pasien memulai pengobatan pada tahun 2016, 119 pasien pada tahun 2017, dan pada tahun 2018 sebanyak 136 pasien.

\section{a. Karakteristik Usia Pasien HIV/AIDS}

Tabel 1. Distribusi Pasien HIV/AIDS

\begin{tabular}{lcc} 
Usia (tahurdint & & (\%) \\
\hline$\leq 19$ & 17 & 5,1 \\
$20-29$ & 159 & 47,7 \\
$30-39$ & 106 & 31,8 \\
$40-49$ & 36 & 10,8 \\
& & \\
$\geq 50$ & 15 & 4,5 \\
Total & $\mathbf{3 3 3}$ & $\mathbf{1 0 0}$ \\
\hline
\end{tabular}

Tabel 1 menyatakan frekuensi usia pasien HIV/AIDS terbanyak ditemukan pada usia antara 20-29 tahun, yaitu sebanyak 159 pasien $(47,7 \%)$. Hasil penelitian ini sejalan dengan penelitian yang dilakukan oleh Kalalo, Tjitrosantoso, \& Goenawi (2012) di Manado bahwa jumlah penderita HIV/AIDS terbanyak pada kelompok usia $20-29$ tahun $(39,43 \%)$. Penelitian Ibrahim, H, Rahayuwati, Nurmalisa \& Fitri (2017) di Bandung juga sesuai yaitu sebagian besar $(66,2 \%)$ responden berusia $20-29$ tahun.

Infeksi HIV lebih banyak terjadi pada usia muda (12-35 tahun) daripada usia tua (36-65 tahun), ini disebabkan karena kurangnya pencegahan penularan HIV pada usia muda yang mungkin lebih banyak melakukan perilaku seks tidak aman yang berisiko terhadap penularan HIV (Kambu, Waluyo, \&

\section{*Corresponding Author :}

\section{Andi Juhaefah}

Program Studi Kedokteran, Fakultas Kedokteran

Universitas Mulawarman

Email : efaandy20@gmail.com
Kuntarti, 2016). Selain itu, pada rentang usia 15-35 tahun, juga merupakan kelompok usia yang rawan terpapar penyalahgunaan narkoba (Badan Narkotika Nasional $\mathrm{RI}, 2019)$.

Berbeda dengan penelitian yang dilakukan oleh Anwar, Nugroho, \& Tantri (2018) di Jakarta bahwa jumlah pasien HIV/AIDS paling banyak berada pada kategori usia 30-39 tahun diikuti usia 20-29 tahun. Tetapi, dari hasil penelitian tersebut, dapat disimpulkan bahwa infeksi HIV/AIDS paling banyak terjadi pada kelompok usia produktif, yaitu 20-49 tahun. Hal ini sesuai dengan data Ditjen P2P Kementerian Kesehatan RI (2018) bahwa persentase infeksi HIV tahun 2017 tertinggi pada kelompok usia 25-49 tahun dan diikuti kelompok usia 20-24 tahun.

\section{b. Karakteristik Jenis Kelamin Pasien HIV/AIDS}

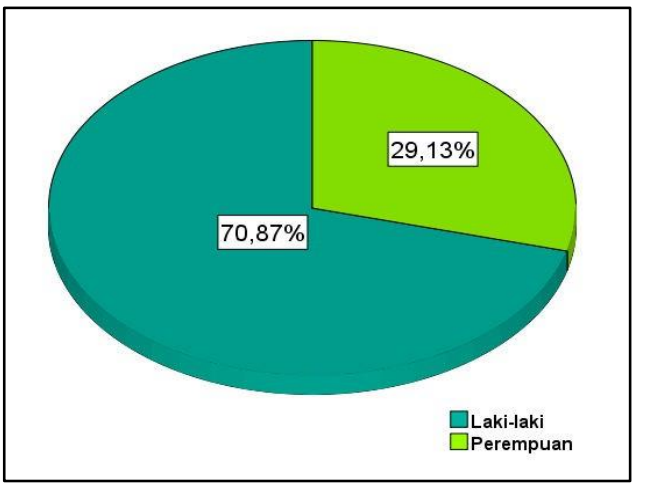

Gambar 1. Distribusi Pasien HIV/AIDS berdasarkan Jenis Kelamin

Gambar 1 menunjukkan bahwa dari 333 pasien, sebanyak 236 pasien adalah laki-laki $(70,87 \%)$ dan perempuan sebanyak 97 pasien $(29,13 \%)$. Berdasarkan angka tersebut, diperoleh rasio laki-laki dan perempuan adalah 2,4:1. Artinya, pasien HIV/AIDS pada laki-laki 2,4 kali lebih banyak dibandingkan pada perempuan. Hal ini sesuai dengan penelitian Puspasari, Wisaksana \& 
Ruslami (2015) di Bandung, didapatkan pasien HIV didominasi oleh laki-laki dengan perbandingan 2,2:1 untuk laki-laki $69,2 \%$ dan perempuan $30,8 \%$. Hasil penelitian ini juga sejalan dengan data yang dilaporkan oleh Ditjen P2P Kemenkes RI (2018) bahwa penderita HIV/AIDS terbanyak ialah laki-laki dengan rasio antara 2:1.

Tingginya proporsi laki-laki yang menderita HIV/AIDS diasumsikan karena banyaknya laki-laki yang melakukan hubungan seksual berisiko dan menggunakan napza suntik dibandingkan perempuan yang lebih sering mendapatkannya dari pasangan seksual mereka (Saktina \& Satriyasa, 2017).

\section{c. Karakteristik Domisili Pasien HIV/AIDS}

Tabel 2. Distribusi Pasien HIV/AIDS per Kabupaten/Kota

\begin{tabular}{lcc}
\hline Kabupaten & (n) & (\%) \\
\hline Samarinda & 293 & 88 \\
Kutai Kartanegara & 27 & 8,1 \\
Balikpapan & 3 & 0,9 \\
Berau & 3 & 0,9 \\
Bontang & 2 & 0,6 \\
Kutai Barat & 2 & 0,6 \\
Kutai Timur & 2 & 0,6 \\
Tidak Diketahui & 1 & 0,3 \\
Total & $\mathbf{3 3 3}$ & $\mathbf{1 0 0}$ \\
\hline
\end{tabular}

Hasil dari analisis data pada Tabel 2 diketahui pasien terbanyak berasal dari Kota Samarinda, yaitu sebanyak 293 pasien (88\%) dan dari luar Kota Samarinda sebanyak 39 pasien $(11,7 \%)$. Sementara itu, 1 pasien tidak melaporkan asal domisili.

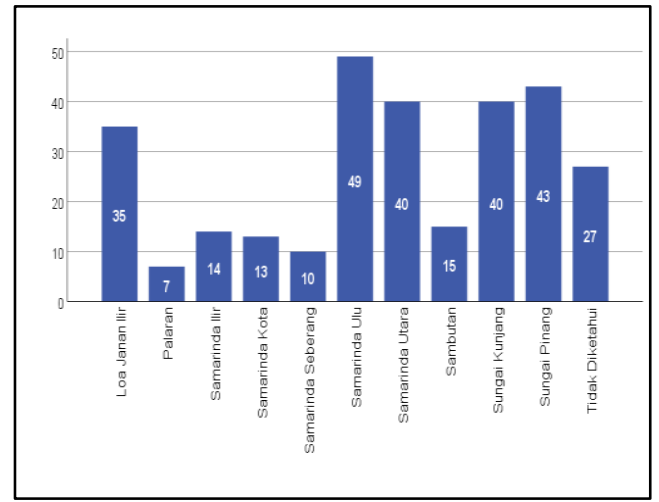

Gambar 2. Distribusi Pasien

HIV/AIDS per Kecamatan di Kota Samarinda

Gambar 2 menunjukkan bahwa pasien HIV/AIDS di Kota Samarinda tersebar di 10 kecamatan. Urutan tertinggi jumlah ODHA se-Kota Samarinda berada di Kecamatan Samarindu Ulu (14,7\%), Sungai Pinang $(12,6 \%)$, Samarinda Utara dan Sungai Kunjang masing-masing $12 \%$, dan Loa Janan Ilir (10,5\%). Sementara itu, sebesar $8,4 \%$ tidak melaporkan letak kecamatan.

Tingginya kejadian HIV/AIDS di Kecamatan Sungai Pinang, Samarinda Utara, dan Loa Janan Ilir diduga karena adanya lokalisasi prostitusi yang berada di daerah tersebut. Di Kota Samarinda, terkenal beberapa tempat lokalisasi prostitusi yang diperkirakan sebagai tempat berisiko tinggi terjadinya proses penularan HIV/AIDS melalui hubungan seksual, yakni lokalisasi Gunung Taraf Bayur di Kecamatan Samarinda Utara, lokalisasi Bandang Raya Solong di Kecamatan Sungai Pinang, dan lokalisasi Suka Damai Loa Hui di Kecamatan Loa Janan Ilir.

Penutupan lokalisasi prostitusi tidak menghentikan transaksi seks, bahkan Pekerja Seks Komersial (PSK) melakukan kegiatan secara terselubung, termasuk adanya prostitusi online di dunia maya sehingga tempat-tempat prostitusi

\footnotetext{
*Corresponding Author:

Andi Juhaefah

Program Studi Kedokteran, Fakultas Kedokteran

Universitas Mulawarman

Email : efaandy20@gmail.com
} 
semakin menyebar dan sembunyisembunyi (Dimas, 2019). Penutupan lokalisasi prostitusi berdampak terhadap timbulnya transaksi prostitusi yang dilakukan secara sembunyi-sembunyi pada eks lokalisasi prostitusi dan secara tidak langsung, mendorong timbulnya hotspot-hotspot baru dan bentukbentuk baru dalam cara berinteraksi. Penutupan lokalisasi prostitusi juga akan menghentikan pemantauan kesehatan di eks lokalisasi prostitusi, serta adanya rasa traumatis dan ketakutan pada para PSK/WPS/PS yang beroperasi di eks lokalisasi prostitusi tersebut (Inayah et a/., 2014).

Tingginya kejadian HIV/AIDS di Kecamatan Samarinda Ulu dan Kecamatan Sungai Kunjang menggambarkan bahwa letak lokalisasi prostitusi kurang berpengaruh terhadap tingkat kejadian HIV/AIDS disuatu daerah. Kecamatan Samarinda Ulu memiliki persentase penduduk tertinggi di Samarinda, yaitu sebesar 14,89\% dengan kepadatan penduduk $5.777 / \mathrm{km}^{2}$, sedangkan Kecamatan Sungai Kunjang menempati posisi ke-tiga setelah Kecamatan Samarinda Utara, yaitu persentase penduduk sebesar $13,97 \%$ dengan kepadatan penduduk $2.785 / \mathrm{km}^{2}$ (BPS Kota Samarinda, 2019).

Dari hasil penelitian tersebut, dapat disimpulkan bahwa tingginya kejadian HIV/AIDS tidak hanya dipengaruhi oleh jarak lokalisasi prostitusi, tetapi juga dipengaruhi oleh kepadatan penduduk dan jumlah penduduk suatu daerah. Penelitian yang mendukung dilakukakn oleh (Khairunisa \& Sihaloho, 2019) yang menyatakan bahwa tingkat kepadatan penduduk yang dihitung dengan membagi antara jumlah penduduk dengan luas area yang ditempati, mempengaruhi kasus HIV/AIDS di Indonesia.

\section{d. Karakteristik Status Pendidikan Pasien HIV/AIDS}

Tabel 3. Distribusi Pasien HIV/AIDS berdasarkan Status Pendidikan

\begin{tabular}{lcc}
\hline Status Pendidikan & (n) & (\%) \\
\hline Tidak Sekolah & 2 & 0,6 \\
SD & 46 & 13,8 \\
SMP & 50 & 15 \\
SMA & 174 & 52,3 \\
D3 & 16 & 4,8 \\
S1 & 45 & 13,5 \\
Total & $\mathbf{3 3 3}$ & $\mathbf{1 0 0}$ \\
\hline
\end{tabular}

Tabel 3 menunjukkan bahwa pasien HIV/AIDS berdasarkan status pendidikan paling banyak dengan tingkat pendidikan terakhir tamat SMA, yakni sebanyak 174 pasien $(52,3 \%)$. Hasil penelitian ini sejalan dengan penelitian Anwar et al., (2017) di Jakarta bahwa paling banyak pada tingkat pendidikan terakhir tamat SMA sebesar 50,81\%. Penelitian Yuliandra et al., (2017) di Padang, juga sejalan dengan hasil penelitian peneliti, yaitu tingkat pendidikan SMA $(56,18 \%)$.

\section{e. Karakteristik Status Marital} Pasien HIV/AIDS

Tabel 4. Distribusi Pasien HIV/AIDS berdasarkan Status Marital

\begin{tabular}{lcc}
\hline \multicolumn{1}{c}{ Status Marital } & $(\mathbf{n})$ & $(\%)$ \\
\hline Belum Menikah & 157 & 47,1 \\
Menikah & 132 & 39,6 \\
Janda / Duda & 44 & 13,2 \\
Total & $\mathbf{3 3 3}$ & $\mathbf{1 0 0}$ \\
\hline
\end{tabular}

Tabel 4 menunjukkan bahwa pasien dengan status belum menikah lebih banyak dibanding pasien dengan status telah menikah dan status janda/duda. Pasien dengan status belum menikah sebanyak 157 pasien $(47,1 \%)$, status telah menikah

\section{*Corresponding Author:}

\section{Andi Juhaefah}

Program Studi Kedokteran, Fakultas Kedokteran

Universitas Mulawarman

Email : efaandy20@gmail.com 
sebanyak 132 pasien $(39,6 \%)$, dan status janda/duda sebanyak 44 pasien $(13,2 \%)$. Hasil ini berbeda dengan penelitian Nyoko et al., (2016) di Sumba Timur, pasien dengan status marital tertinggi adalah menikah sebanyak 62,2\%. Hasil penelitian Yuliandra et al., (2017) di Padang, juga menyatakan bahwa pasien dengan status marital tertinggi adalah menikah $(58,43 \%)$.

Status perkawinan diduga memiliki peranan seksual antara seorang laki-laki yang sudah menikah dan yang belum menikah. Laki-laki yang sudah menikah akan berperilaku sehat dan bertanggungjawab dalam melakukan hubungan seksual dengan pasangannya karena tidak menginginkan dampak negatif dari hubungan seks tersebut. Secara teoritis, seseorang yang berstatus belum/tidak menikah mempunyai tingkat perilaku seks yang lebih berisiko, karena untuk melampiaskan hasrat seksualnya mereka cenderung untuk mengakses WPS (Sugiarto, 2017).

\section{f. Karakteristik Faktor Risiko Pasien HIV/AIDS}

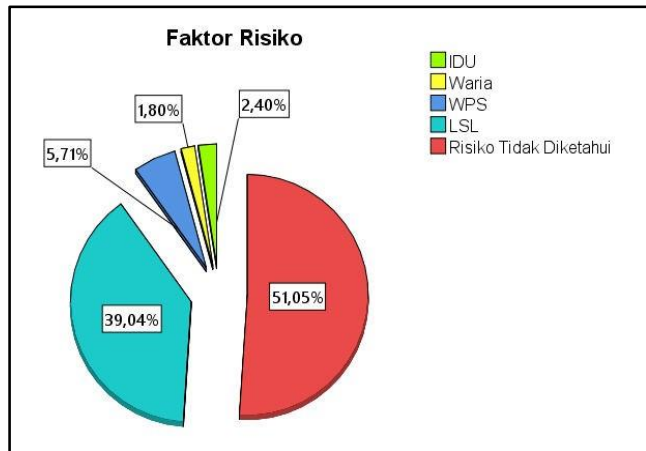

Gambar 3. Distribusi Pasien HIV/AIDS berdasarkan Faktor Risiko
Gambar 3 menunjukkan bahwa faktor risiko penularan HIV/AIDS tertinggi di Samarinda adalah hubungan seks berisiko pada LSL 130 orang (39\%), berikutnya pada WPS 19 orang $(5,7 \%)$ dan penggunaan alat suntik tidak steril pada penasun (IDU) sebanyak 8 orang $(2,4 \%)$, serta hubungan seks berisiko pada waria sebanyak 6 orang $(1,8 \%)$. Sementara itu, 170 orang $(51,1 \%)$ tidak melaporkan faktor risiko penularan.

Hasil penelitian ini sejalan dengan laporan perkembangan HIVAIDS dan PIMS di Indonesia yang menyatakan bahwa persentase infeksi HIV yang dilaporkan menurut faktor risiko tahun 2017 yang didapat dari layanan KTS, tertinggi pada LSL dengan 11.630 orang, diikuti heteroseksual 10.779 orang, dan Penasun (IDU) sebanyak 832 orang (Kementerian Kesehatan RI, 2018)

Perilaku berhubungan seks pada LSL secara anal sangat berisiko terinfeksi HIV. Anus tidak seperti organ reproduksi wanita atau vagina yang dapat melubrikasi (melumasi) sehingga melakukan hubungan seks melalui anal berisiko terjadinya luka atau lecet pada jaringan anus (Firdaus \& Agustin, 2013). Virus HIV akan berada di dalam semen, baik ekstrasel ataupun di dalam sel inflamasi mononukleus, dan masuk ke dalam tubuh resipien melalui laserasi atau abrasi pada mukosa. Penularan melalui hubungan seks juga dibantu dan ditambah oleh adanya penyakit IMS lain, yang menyebabkan laserasi genital (Kumar et al., 2015).

Sementara itu, sebanyak 170 orang $(51,1 \%)$ tidak melaporkan faktor risiko penularan. Kemungkinan, merupakan pelanggan PS atau ibu rumah tangga, mengingat angka kejadian infeksi HIV/AIDS pada kelompok tersebut

* Corresponding Author:

Andi Juhaefah

Program Studi Kedokteran, Fakultas Kedokteran

Universitas Mulawarman

Email : efaandy20@gmail.com 
sangatlah tinggi. Berdasarkan hasil penelitian Yuliandra et al., (2017) di Padang bahwa faktor risiko penularan terbesar adalah melalui seks dengan partner seks terbanyak adalah WPS, yaitu sebesar $38,33 \%$. Berdasarkan hasil survei yang dilakukan BPS, BKKBN, Kemenkes \& ICF (2013, dalam ibrahim et al., 2017) didapatkan bahwa seorang WPS yang terinfeksi HIV/AIDS sedikitnya dapat menularkan kepada 6 pria yang melakukan hubungan seks dengannya.

\section{g. Karakteristik Asal Puskesmas Pasien HIV/AIDS}

Tabel 5. Distribusi Pasien HIV/AIDS berdasarkan Asal Puskesmas

\begin{tabular}{lcc}
\hline $\begin{array}{l}\text { Asal } \\
\text { Puskesmas }\end{array}$ & $(\mathbf{n})$ & $\mathbf{( \% )}$ \\
\hline Temindung & 147 & 44,1 \\
Sempaja & 62 & 18,6 \\
Karang Asam & 33 & 9,9 \\
Trauma Center & 30 & 9 \\
Bengkuring & 22 & 6,6 \\
Sidomulyo & 19 & 5,7 \\
Palaran & 11 & 3,3 \\
Sungai Siring & 6 & 1,8 \\
Bantuas & 3 & 0,9 \\
Total & $\mathbf{3 3 3}$ & $\mathbf{1 0 0}$ \\
\hline
\end{tabular}

Berdasarkan Tabel 5 didapatkan persentase terbanyak pasien HIV/AIDS berdasarkan karakteristik asal puskesmas adalah Puskesmas Temindung sebanyak 147 orang atau sebesar $44,1 \%$.

Dalam menghadapi stigma dan atau diskriminasi secara umum, ODHA melakukan dua strategi. Pertama, ODHA berusaha menutupi status HIV/AIDSnya di depan umum, oleh karena sebagian masyarakat belum memiliki pemahaman yang benar tentang HIV/AIDS. Ini dilakukan untuk menjaga agar jangan sampai dirinya, keluarga, atau bahkan keluarga besarnya mengalami stigma. Salah satu upaya untuk menjaga kerahasian statusnya dari lingkungan tempat tinggalnya, yaitu dengan memilih melakukan pengobatan ARV di luar kota. Ini merupakan praktik dari teori dramaturgi. Di panggung depan memaikan peran bukan sebagai ODHA, di hadapan anak-anak, keluarga, dan anggota masyarakat di tempat domisilinya, serta di tempat kerja. Di panggung belakang, saat memeriksakan kesehatan dan mengambil obat ARV, barulah mereka menampilkan jati diri sebenarnya sebagai ODHA. Strategi kedua adalah bagi orang-orang yang percaya diri, pasrah, atau memiliki dukungan yang solid sehingga dapat berterus terang mengenai keadaannya (Makmur, 2017).

\section{h. Karakteristik Jenis Terapi ARV Pasien HIV/AIDS}

Tabel 6. Distribusi Pasien HIV/AIDS berdasarkan Jenis ARV

\begin{tabular}{lcc}
\hline Jenis ARV & (n) & (\%) \\
\hline TDF + FTC + EFV & 284 & 85,3 \\
TDF + 3TC + EFV & 46 & 13,8 \\
ZDV + 3TC + NVP & 2 & 0,6 \\
TDF + 3TC + RPV & 1 & 0,3 \\
Total & $\mathbf{3 3 3}$ & $\mathbf{1 0 0}$ \\
\hline
\end{tabular}

Tabel 6 menunjukkan bahwa jenis ARV yang lebih banyak digunakan, yaitu rejimen TDF + FTC + EFV berjumlah 284 pasien (85,3\%). Keempat kategori rejimen tersebut merupakan kategori lini pertama dalam terapi antiretroviral. Berdasarkan pedoman WHO (2013), ART lini pertama harus terdiri dari kombinasi dua nucleoside reversetranscriptase inhibitors (NRTIs) ditambah satu non nucleoside reverse-transcriptase inhibitors (NNRTIs).

\section{*Corresponding Author:}

\section{Andi Juhaefah}

Program Studi Kedokteran, Fakultas Kedokteran

Universitas Mulawarman

Email : efaandy20@gmail.com 
Mekanisme kerja obat ARV golongan NRTI adalah menghambat enzim reverse transcriptase sehingga pertumbuhan rantai DNA dan replikasi HIV terhenti, bertindak sebagai umpan dengan meniru nukleotida inang dan menyebabkan penghentian rantai DNA HIV yang memanjang. Contoh NRTI, yaitu zidovudine (AZT), lamivudine (3TC), abacavir (ABC), stavudin (d4T), didanosine (ddl), emtricitabine (FTC), dan tenofovir (TDF). Mekanisme kerja obat ARV golongan NNRTI adalah menghambat transkripsi RNA HIV menjadi DNA dengan mengikat langsung ke enzim reverse transcriptase HIV dan menghambat fungsi enzim. Contoh NRTI, yaitu Nevirapine (NVP), Efavirenz (EFV), Rilpivirine (RPV), Etravirine (ETR), dan Doravirine (DOR) (Spach, H.D, 2018).

TDF $+3 T C(F T C)+E F V$ merupakan kombinasi pilihan utama untuk pengobatan HIV/AIDS, hal ini mengakibatkan sebagian besar pasien menggunakan rejimen obat tersebut. Sementara itu, ZDV + 3TC + NVP dan TDF + 3TC + RPV merupakan pilihan alternatif yang digunakan apabila terdapat kontraindikasi, efek samping, atau tidak tersedianya pilihan utama.

\section{KESIMPULAN}

Berdasarkan hasil dan pembahasan yang telah dipaparkan bahwa dari total 333 pasien HIV/AIDS yang mendapat ART di 9 puskesmas di Kota Samarinda, dapat disimpulkan, yakni pasien lebih banyak berusia 20-29 tahun sebanyak 159 pasien dan pasien lakilaki lebih banyak, yaitu 236 pasien karena cenderung melakukan perilaku seks yang tidak aman yang berisiko terhadap penularan HIV dan menggunakan napza suntik. Pasien terbanyak berasal dari Kota

\section{*Corresponding Author :}

\section{Andi Juhaefah}

Program Studi Kedokteran, Fakultas Kedokteran

Universitas Mulawarman

Email : efaandy20@gmail.com
Samarinda, yaitu sebanyak 293 pasien, dengan pasien paling banyak dilaporkan berasal dari Kecamatan Samarinda Ulu sebanyak 49 pasien karena memiliki kepadatan penduduk tertinggi di Kota Samarinda.

Pada status pendidikan pasien, terdapat 174 pasien dengan tingkat pendidikan terakhir tamat SMA karena status pendidikan dengan tingkat SMA/MA/SMK merupakan lulusan terbanyak di Kalimantan Timur dan orang dengan pendidikan SMA dipandang memiliki kesadaran untuk melakukan pemeriksaan secara sukarela. Pada status marital pasien, terdapat 157 pasien berstatus belum menikah karena berhubungan erat dengan perilaku seksual berisiko. Faktor risiko tertinggi adalah hubungan seks berisko pada LSL, yaitu sebanyak 130 pasien karena cenderung memiliki banyak pasangan seks, berganti-ganti pasangan, dan melakukan seks anal yang berisiko terhadap penularan HIV/AIDS.

Berdasarkan asal puskesmas, Puskesmas Temindung yang paling banyak, yaitu 147 pasien karena dipengaruhi oleh jumlah penduduk dalam wilayah kerja puskesmas tersebut yang lebih banyak dibanding puskesmas lain dan adanya pasien dari luar wilayah kerja Puskesmas Temindung yang melakukan pengobatan di puskesmas tersebut, diduga karena pasien menghindari stigma masyarakat di sekitar wilayah tempat tinggalnya. Jenis ARV yang paling banyak digunakan adalah rejimen TDF+FTC+EFV berjumlah 284 orang.

\section{DAFTAR PUSTAKA}

Afifah, Y.N., Saraswati, E. (2014). Pemanfaatan Sistem Informasi Geografis (SIG) untuk Kajian Kartografis Persebaran 
Penyakit HIV di Kota Semarang Tahun 2012. Jurnal Bumi Indonesia.

Anwar, Y., Nugroho, S.A., Tantri, N.D. (2018). Karakteristik Sosiodemografi, Klinis, dan Pola Terapi Antiretroviral Pasien HIV/AIDS di RSPI Prof. Dr. Sulianti Saroso Periode JanuariJuni 2016. Pharmaceutical Journal of Indonesia, 15(1):7288.

Badan Narkotika Nasional RI. (2019). Penggunaan Narkotika di Kalangan Remaja Meningkat. Diunduh dari https://bnn.go.id/penggunaannarkotika-kalangan-remajameningkat/

Badan Pusat Statistik Kota Semarang. (2018). Indikator Perkembangan Penduduk Kota Semarang. Diunduh dari https://semarangkota.bps.go.id/

Badan Pusat Statistik Kota Samarinda. (2019). Penduduk, Laju Pertumbuhan Penduduk, Distribusi Penduduk, Kepadatan Penduduk, Rasio Jenis Kelamin Penduduk Menurut Kecamatan di Kota Samarinda, 2010, 2017, dan 2018. Diunduh dari https://samarindakota.bps.go.id

Chawla, N., \& Sarkar, S. (2019). Defining "High-risk Sexual Behavior" in the Context of Substance Use. Journal of Psychosexual Health, 1(1): 2631

Dewi, D.M.S.K., Wulandari, L.P.L., \& Karmaya, N.M. (2013). Kerentanan Perempuan terhadap Penularan IMS dan HIV: Gambaran Perilaku Seksual
Berisiko di Kota Denpasar. Public Health and Preventive Medicine Archive.

Dimas, C. (2019, 25 Maret ). Lokalisasi Prostitusi di Kaltim Dibubarkan, Pemantauan Sulit, Semakin Menyebar dan Terselubung. Tribun Kaltim. Diunduh dari http://kaltim.tribunnews.com/amp /2019/03/20/lokalisasi-prostitusidi-kaltim-dibubarkanpemantauan-sulit-semakinmenyebar-terselubung.

Dinas Kesehatan Provinsi Kalimantan Timur. (2018). Profil Kesehatan Provinsi Kalimantan Timur Tahun 2017.

Firdaus, S., Agustin, H. (2013). Faktor Risiko Kejadian HIV pada Komunitas LSL (Lelaki Seks dengan Lelaki) Mitra Yayasan Lantera Minangkabau Sumatera Barat. Jurnal Kesehatan Komunitas, 2(2): 94-99

Ibrahim, K., H, Y.K., Rahayuwati, L., Nurmalisa, B.E., \& Fitri, S.U.R. (2017). Hubungan antara Fatigue, Jumlah CD4, dan Kadar Hemoglobin pada Pasien yang Terinfeksi Human Immunodeficiency Virus (HIV). Jurnal Keperawatan Padjadjaran, 5(3): 274-275.

Inayah, N., Sugiyono., Biati, L., Andriani, Z.Z.D., Aminah, S., Syafaat, A.M., Syafa'at, A.K. (2014). Kajian Dampak Penutupan Lokalisasi di Kabupaten Banyuwangi. Lembaga Penelitian dan Pengabdian Masyarakat Sekolah

*Corresponding Author:

Andi Juhaefah

Program Studi Kedokteran, Fakultas Kedokteran

Universitas Mulawarman

Email : efaandy20@gmail.com 
Tinggi Agama Islam Darussalam Banyuwangi.

Kalalo, J.G.K., Tjitrosantoso, H.M., \& Goenawi, L.R. 2012. Studi Penatalaksanaan Terapi pada Penderita HIV/AIDS di Klinik VCT Rumah Sakit Kota Manado. Jurnal Ilmiah Pharmacon Universitas Sam Ratulangi, 1(2): 98-103.

Kambu, Y., Waluyo, A., \& Kuntarti. (2016). Umur Orang dengan HIV AIDS (ODHA) Berhubungan dengan Tindakan Pencegahan Penularan HIV. Jurnal Keperawatan Indonesia Universitas Indonesia, 19(3): 200-207.

Khairunisa, N. S., \& Sihaloho, E. D. (2019). Determinan Pembangunan Daerah dan Angka HIV/AIDS di Indonesia. Ekonomikawan: Jurnal IImu Ekonomi Dan Studi Pembangunan, 19(1).

Kementerian Kesehatan RI. (2018). Laporan Situasi Perkembangan HIV-AIDS \& PMS di Indonesia Januari - Desember 2017. Direktorat Jenderal Pencegahan dan Pengendalian Penyakit. Jakarta, Indonesia.

Kumar, V., Abbas, A.K., \& Aster, J.C., (2015). Buku Ajar Patologi Robbins. Singapore: Eleavier.

Laksana, A.S.D., Lestari, D.W.D. (2010). Faktor-Faktor Risiko Penularan HIV/AIDS pada LakiLaki dengan Orientasi Seks Heteroseksual dan Homoseksual

\section{*Corresponding Author :}

\section{Andi Juhaefah}

Program Studi Kedokteran, Fakultas Kedokteran Universitas Mulawarman

Email : efaandy20@gmail.com di Purwokerto. Mandala of Health, 4(2): 113-123.

Makmur, R. (2017). Strategi Komunikasi Orang dengan HIV AIDS (ODHA) Menghadapi Stigma Masyarakat. LUGAS Jurnal Komunikasi, 1(1): 68-83.

Nyoko, Y.O., Hara, M.K., \& Abselian, U.P. (2016). Karakteristik Penderita HIV/AIDS di Sumba Timur Tahun 2010-2016. Jurnal Kesehatan Primer, 1(1):4-15.

Pemerintahan Provinsi Kalimantan Timur. (2016). Per 1 Juni 2016 Semua Lokalisasi di Kaltim Ditutup. Diunduh dari https://kaltimprov.go.id/berita/per1-juni-2016-semua-lokalisasi-dikaltim-ditutup

Purba, R. (2016). Karakteristik Pasien HIV/AIDS yang Berobat Jalan di RSUD Dr. Pirngadi Medan Tahun 2015. Skripsi. Universitas Sumatera Utara.

Puspasari, D., Wisaksana, R., \& Ruslami, R. (2018). Gambaran Efek Samping dan kepatuhan Terapi Antiretroviral pada Pasien HIV di Rumah Sakit Dr. Hasan Sadikin Bandung Tahun 2015. Jurnal Sistem Kesehatan Fakultas Kedokteran Universitas Padjadjaran, 3(4):175-181.

Saktina, P. U., \& Satriyasa, B. K. (2017). Karakteristik Penderita AIDS dan Infeksi Oportunistik di Rumah Sakit Umum Pusat Sanglah Denpasar Periode Juli 
2013 sampai Juni 2014. E-Jurnal Medika, 6(3).

Spach, H.D. (2018). Antiretroviral Medications and Initial Therapy. Dalam National HIV Curriculum. https://www.hiv.uw.edu

Sugiarto. (2017). Hubungan Status Pernikahan dan Kepemilikan Kondom dengan Penggunaan Kondom saat Melakukan Hubungan Seksual pada Pasangan Tidak Tetap Pengguna Napza Suntik. Jurnal Kesehatan Terpadu 1(2):44-48

UNAIDS. (2018). Overview HIV/AIDS in Indonesia [WWW Document]. UNAIDS. Wisaksana, R., Alisjahbana, B., Crevel, R. van, Kesumah, N., Sudjana, P., Sumantri, R., 2009. Challenges in delivering HIV-care in Indonesia: Experience from a Referral Hospital. Acta Med. Indones. 41, 45-51.

World Health Organization. (2013). Consolidated Guidelines On The Use of Antiretroviral Drugs for Treating and Preventing HIV Infection. (hal.30-32)

World Health Organization. (2017a). HIV/AIDS Fact Sheet [WWW Document].World Heal. Organ.

World Health Organization. (2017b). HIV/AIDS Global Health Observatory Data [WWW Document]. World Heal. Organ.

Yuliandra, Y., Nosa, U. S., Raveinal, \& Almasdy, D. (2017). Terapi Antiretroviral pada Pasien

*Corresponding Author :

\section{Andi Juhaefah}

Program Studi Kedokteran, Fakultas Kedokteran Universitas Mulawarman

Email : efaandy20@gmail.com
HIV/AIDS di RSUP. Dr. M. Djamil Padang: Kajian Sosiodemografi dan Evaluasi Obat. Jurnal Sains Farmasi \& Klinis.

Yulianti, A.P. (2013). Kerentanan Perempuan terhadap Penularan HIV \& AIDS: Studi pada lbu Rumah Tangga Pengidap HIV/AIDS di Kabupaten Pati, Jawa Tengah. Palastren: Jurnal Studi Gender, 6(1): 185-200 